McCance, R. A. \& Widdowson, E. M. (1947). I. Hyg., Camb., 45, 59.

Mitchell, H. H. \& Carman, G. G. (1924). F. biol. Chem. 60, 613.

Mitchell, H. H. \& Carman, G. G. (1926). F. biol. Chem. 68, 183.

Murlin, J. R., Marshall, M. E. \& Kochakian, C. D. (194I). F. Nutrit. 22, 573.

Platt, B. S. (1936). Chin. med. J. 50, 140.

Platt, B. S. (1939). Nutrition in the Colonial Empire. London: H. M. Stationery Office.

Saiki, T. (1930). My Principles of Nutrition. Tokyo.

Widdowson, E. M. (1936). F. Hyg., Camb., 36, 269.

Widdowson, E. M. \& McCance, R. A. (1936). J. Hyg., Camb., 36, I3.

\title{
A Comparison of Acid and Enzymic Extraction of Nicotinic Acid from Foodstuffs
}

\author{
By KAMALA SOHONIE AND L. C. MISRA \\ Institute of Science, Bombay, India
}

(Received 25 Yanuary 1950)

The procedure commonly employed for the extraction of nicotinic acid from foodstuffs involves the use of either acid or alkali (Swaminathan, 1938-9, 1942a-c, I944; Harris \& Raymond, 1939; Bandier \& Hald, 1939; Melnick \& Field, 1940a; Kodicek, $1940 a, b)$. This procedure is so drastic that highly coloured extracts, especially with materials of plant origin, are often obtained, and this necessitates separate blank estimations. Further, the manner of evaluating the blank has been shown by Melnick $\&$ Field $(1940 a, b)$ to influence the nicotinic-acid values. Extraction of nicotinic acid from biological materials has been achieved comparatively recently by the use of enzymes such as takadiastase and pepsin (Cheldelin \& Williams, 1942) or an enzyme preparation from the intestinal mucosa of the pig (Bhagvat, 1943). The last preparation contains a large array of enzymes that will extract and liberate nicotinic acid from biological combination. Further, extraction of nicotinic acid from foodstuffs by the extract of pig's mucosa yields colourless, or only slightly coloured, extracts, thereby completely eliminating the need for blanks. The present investigation was undertaken to compare the nicotinic-acid contents of foodstuffs determined after their extraction with $2 \mathrm{~N}-\mathrm{HCl}$ or with an enzyme preparation from the intestinal mucosa of the pig.

\section{EXPERIMENTAL}

Preparation of the enzyme. The intestinal mucosa of the pig was used since it is known to contain a large and varied array of enzymes and is easily obtainable. To a thick viscous suspension of the mucosa an equal volume of $1.0 \%$ saline was added and the mixture was centrifuged. The supernatant liquid was discarded, the residue was suspended in an equal volume of $1.0 \%$ saline and preserved in the ice-box under toluene. The activity of the preparation, which contained proteases, phosphatases, nucleotidases and other enzymes, was found to keep for months. No attempt was made to purify the preparation further, since the object was merely to liberate and extract 
nicotinic acid from its biological combinations, and the preparation was found to be completely devoid of nicotinic acid.

Preparation of the enzyme extracts of the foodstuffs. From I to ro g. of the finely powdered materials were well mixed with 50-100 ml. of phosphate buffer, $\mathrm{pH} 6-7$, or with water and the $\mathrm{pH}$ was adjusted to $6-7$ by the addition of $5 \%$ sodium-acetate solution. The enzyme preparation ( $\mathrm{I} \mathrm{ml}$.) was added and the mixture was incubated overnight at $37^{\circ}$ with toluene as a preservative. The mixture was centrifuged, the residue was washed once with phosphate buffer or sodium-acetate solution. The centrifugates were mixed and made up to 50-100 ml. The interfering substances were removed by the addition of basic lead acetate, excess of which was removed by the addition of sulphuric acid. The extracts, which in every case were almost colourless, were hydrolysed for half an hour on a water-bath and were tested for their nicotinic-acid content by the cyanogenbromide-aniline method as used by Bhagvat (1943).

Acid extraction. The acid extracts were prepared by extracting $\mathrm{I}-\mathrm{I} 0 \mathrm{~g}$. of the foodstuff with $50 \mathrm{ml} .2 \mathrm{~N}-\mathrm{HCl}$ for $15-20 \mathrm{~min}$. on the water-bath. The extracts were filtered, neutralized and treated with $\mathrm{r} 0 \mathrm{ml}$. of a $50 \%$ solution of basic lead acetate. The excess of lead was removed by the addition of $3 \mathrm{ml} .6 \mathrm{~N}-\mathrm{H}_{2} \mathrm{SO}_{4}$. The filtrates were heated on the water-bath for 40-60 min. to hydrolyse nicotinic-acid amide to the acid, and were then neutralized. The nicotinic acid in the extracts was estimated by the cyanogenbromide-aniline method. Since acid extracts from most foodstuffs were coloured, two blank estimations were made in every instance: ( 1 ) dilution blank, a known portion of the extract diluted with water to $25 \mathrm{ml}$. and the colour compared directly in the colorimeter and (2) aniline blank prepared by using a $2 \%$ aniline solution instead of water.

Nicotinic-acid precursor. A few preliminary experiments were carried out with the different foodstuffs to find out if the precursor of the type described by Krehl \& Strong (1944) was extracted under the experimental conditions described in this paper or by autoclaving the foodstuff with roo times its weight of water at $15 \mathrm{lb}$. pressure for $\mathrm{I}_{5} \mathrm{~min}$. 'The acid, the enzymic and the autoclaved extracts were each divided into two portions; one was treated in the usual way and to the other, after neutralization, $40 \%$ sodiumhydroxide solution was added to $0.25 \%$ concentration. The extracts were left to stand for $6 \mathrm{~min}$. in contact with the alkali, neutralized and treated with basic lead acetate; excess of lead was removed with sulphuric acid. The extracts were then hydrolysed on the waterbath for $40-60 \mathrm{~min}$. and the nicotinic acid was estimated in the usual way. The amount of the precursor present in the foodstuff was expressed as $\mu \mathrm{g}$./g. in terms of nicotinic acid and was obtained by deducting the nicotinic-acid value for the extract before alkali treatment from that obtained after treatment.

\section{RESULTS}

Nicotinic-acid contents of foodstuffs. The values found (Table $\mathbf{I}$ ) for the nicotinic-acid content of foodstuffs, with the exceptions of yeast and liver, vary appreciably with the method of extraction employed. For pulses, a lower value for nicotinic acid was generally obtained by acid than by enzymic extraction. Further, with acid extracts a difference was sometimes found between results calculated from the alternative 
Table I. Nicotinic-acid contents of certain foodstuffs ( $\mu \mathrm{g} . / \mathrm{g}$.

\begin{tabular}{|c|c|c|c|c|c|}
\hline \multirow[b]{2}{*}{ Material } & \multirow[b]{2}{*}{ Botanical name } & \multicolumn{3}{|c|}{ Acid extraction } & \multirow[b]{2}{*}{$\begin{array}{l}\text { Enzymic } \\
\text { extraction }\end{array}$} \\
\hline & & Uncorrected & $\begin{array}{c}\text { Corrected } \\
\text { with dilution } \\
\text { blank }\end{array}$ & $\begin{array}{c}\text { Corrected } \\
\text { with aniline } \\
\text { blank }\end{array}$ & \\
\hline Green gram & Phaseolus radiatus & $41 \cdot 5$ & $14 \cdot 8$ & $10 \cdot 0$ & $16 \cdot 0$ \\
\hline Green gram, sprouted & $P$. radiatus & $7 \cdot 9$ & 0.75 & $-1 \cdot 7$ & $9 \cdot 5$ \\
\hline Horse gram (sample r) & Dolichos biflorus & $18 \cdot 9$ & $13 \cdot 6$ & $9 \cdot 5$ & $15 \cdot 9$ \\
\hline Horse gram (sample 2 ) & D. biflorus & $22 \cdot 3$ & $10 \cdot 1$ & $8 \cdot 9$ & $17 \cdot 9$ \\
\hline Cow pea (sample I) & Vigna sinensis & $8 \cdot I$ & - & - & $15 \cdot 0$ \\
\hline Cow pea (sample 2) & $V$. sinensis & I $x \cdot 3$ & 一 & - & 19.5 \\
\hline $\begin{array}{l}\text { Cow pea, sprouted } \\
\text { (sample I) }\end{array}$ & $V$. sinensis & $12 \cdot 7$ & $5 \cdot 4$ & $6 \cdot 2$ & 14.7 \\
\hline $\begin{array}{l}\text { Cow pea, sprouted } \\
\text { (sample 2) }\end{array}$ & $V$. sinensis & 一 & - & - & $13 \cdot 8$ \\
\hline Black gram (sample I) & Phaseolus mungo & $24 \cdot 2$ & $7 \cdot 5$ & -0.4 & $15 \cdot 1$ \\
\hline Black gram (sample 2) & P. mungo & - & $\therefore$ & - & $18 \cdot 2$ \\
\hline Black gram, sprouted & P. mungo & - & - & $\cdots$ & $14^{\cdot 1}$ \\
\hline Wheat & Triticum vulgare & $44 \cdot 5$ & $29 \cdot 1$ & $26 \cdot 9$ & $15 \cdot 7$ \\
\hline Wheat bran & - & 90.0 & 一 & 一 & $74^{\circ} 0$ \\
\hline Barley (sample I) & Hordeum vulgare & $34 \cdot 7$ & $26 \cdot 9$ & $26 \cdot 9$ & 14.3 \\
\hline Barley (sample 2) & H. vulgare & 30.0 & $21 \cdot 0$ & $21 \cdot 5$ & 10.5 \\
\hline $\begin{array}{l}\text { Groundnut, ether- } \\
\text { extracted (sample I) }\end{array}$ & Arachis hypogoea & 179.5 & $140 \cdot 0$ & 139.5 & $69 \cdot 0$ \\
\hline $\begin{array}{l}\text { Groundnut, ether- } \\
\text { extracted (sample 2) }\end{array}$ & A. hypogoea & $134^{\circ} 0$ & $104 \cdot 0$ & $104 \cdot 0$ & $67 \cdot 8$ \\
\hline Indian mustard & Brassica juncea & $60 \cdot 6$ & $35 \cdot 6$ & $34 \cdot 5$ & $26 \cdot I$ \\
\hline $\begin{array}{l}\text { Indian mustard, chloro- } \\
\text { form-extracted }\end{array}$ & B. juncea & $\cdots$ & - & - & $47 \cdot x$ \\
\hline Sesame seed & Sesamum indicum & $42 \cdot 9$ & $35 \cdot 4$ & $34 \cdot 6$ & $22 \cdot 8$ \\
\hline $\begin{array}{l}\text { Sesame seed, chloro- } \\
\text { form-extracted }\end{array}$ & S. indicum & $89 \cdot 1$ & 80 & $81 \cdot 0$ & $33^{\circ} 9$ \\
\hline Dried yeast ('Torula) & - & 213.0 & -- & 一 & $215 \cdot 0$ \\
\hline Dried brewer's yeast & - & $4^{6} 5 \cdot 0$ & 一. & - & $472 \cdot 0$ \\
\hline Sheep liver & - & 105.0 & 一 & - & $107 \cdot 0$ \\
\hline
\end{tabular}

blank values. However, acid extraction of cereals and oilseeds yielded higher values for nicotinic acid than those obtained by the enzymic method. Whether these high values are due to a precursor of nicotinic acid or to a non-specific chromogen is difficult to say. If the precursor itself has chromogenic properties, this might to some degree invalidate the figures given for the amount of it present. The presence of a precursor of nicotinic acid in wheat bran and certain other natural materials has been reported by Melnick, Oser \& Siegel (194r), by Andrews, Boyd \& Gortner (1942) and by Krehl \& Strong (1944).

Nicotinic-acid precursor. The values found are given in Table 2.

\section{DISCUSSION}

Of the foodstuffs tested, only barley, groundnuts and black gram appear to contain the alkali-labile precursor (Krehl \& Strong, 1944); the amount of the precursor extracted depends on the mode of extraction. Autoclaving appears to extract least; enzyme treatment appears to extract the largest amount from groundnut, whereas acid is more effective with barley than with groundnut. Further, sprouting seems to decrease the content of precursor in black gram. Whether this precursor is biologically active is not 
Table 2. Nicotinic acid and nicotinic-acid precursor in certain foodstuffs ( $\mu \mathrm{g} . / \mathrm{g}$.

\begin{tabular}{|c|c|c|c|c|c|c|c|}
\hline \multirow[b]{2}{*}{ Material } & \multirow[b]{2}{*}{ Botanical name } & \multicolumn{2}{|c|}{ Acid extraction } & \multicolumn{2}{|c|}{ Enzymic extraction } & \multicolumn{2}{|c|}{$\begin{array}{c}\text { Extraction } \\
\text { by autoclaving }\end{array}$} \\
\hline & & $\begin{array}{l}\text { Nicotinic } \\
\text { acid }\end{array}$ & $\begin{array}{l}\text { Nicotinic- } \\
\text { acid } \\
\text { precursor }\end{array}$ & $\begin{array}{l}\text { Nicotinic } \\
\text { acid }\end{array}$ & $\begin{array}{l}\text { Nicotinic- } \\
\text { acid } \\
\text { precursor }\end{array}$ & $\begin{array}{c}\text { Nicotinic } \\
\text { acid }\end{array}$ & $\begin{array}{l}\text { Nicotinic- } \\
\text { acid } \\
\text { precursor }\end{array}$ \\
\hline Cow pea & Vigna sinensis & II 3 & 0.0 & 19.5 & 0.0 & $18 \cdot 5$ & 0.0 \\
\hline Cow pea, sprouted & $V$. sinensis & 一 & 一 & $13 \cdot 8$ & 0.9 & - & - \\
\hline Black gram & Phaseolus mungo & - & 一 & I $8 \cdot 2$ & $6 \cdot 9$ & $15 \cdot 6$ & 0.2 \\
\hline $\begin{array}{l}\text { Black gram, } \\
\text { sprouted }\end{array}$ & $P$. mungo & 一 & 一 & $14 \cdot 1$ & 0.4 & - & - \\
\hline Barley & Hordeum vulgare & $2 I \cdot 0$ & 10.08 & 10.5 & $1 \cdot 6$ & $15 \cdot 6$ & 0.2 \\
\hline $\begin{array}{l}\text { Groundnut, ether- } \\
\text { extracted }\end{array}$ & Arachis hypogoea & $104 \cdot 4$ & $25 \cdot 9$ & $67 \cdot 8$ & 46.8 & $45 \cdot 5$ & $6 \cdot 0$ \\
\hline $\begin{array}{l}\text { Indian mustard, } \\
\text { chloroform-ex- } \\
\text { tracted }\end{array}$ & Brassica juncea & - & - & $47^{\cdot 1}$ & 0.0 & $40 \cdot 1$ & 0.0 \\
\hline Sesame seed, chloro & Sesamum indicum & 80 & 0.0 & $33 \cdot 9$ & $0 \cdot 0$ & $69 \cdot 0$ & 0.0 \\
\hline
\end{tabular}

known. Krehl, Elvehjem \& Strong (1944) have shown that the precursor in wheat and other biological materials is biologically active for dogs but its availability for man is still an open question. The enzyme preparation used in this investigation contains many enzymes that will liberate nicotinic acid from biological combination. Further, taking into consideration the specificity of enzyme action and the presence of similar enzymes in the human intestine, it might not be unreasonable to suggest that the values for nicotinic acid obtained by enzymic extraction represent that biologically available. Further experiments, however, are necessary to prove this.

\section{SUMMARY}

I. A procedure for the extraction of nicotinic acid from foodstuffs with $2 \mathrm{~N}-\mathrm{HCl}$ and with an enzyme preparation from the intestinal mucosa of the pig is described.

2. The two modes of extraction have been shown to yield different values for nicotinic acid, enzymic extraction yielding higher values for pulses and acid extraction for oilseeds and cereals.

3. It is suggested that the discrepancy may be due either to the presence of an alkali-labile precursor of nicotinic acid or of a non-specific chromogen.

4. Groundnuts, barley and black gram were found to contain a precursor.

\section{REFERENCES}

Andrews, J. S., Boyd, H. M. \& Gortner, W. A. (1942). Industr. Engng Chem. (Anal. ed.), 14, 663. Bandier, E. \& Hald, J. (r939). Biochem. $\mathcal{F}$. 33, 264.

Bhagvat, K. (1943). Indian F. med. Res. 31, 145.

Cheldelin, V. H. \& Williams, P. R. (1942). Industr. Engng Chem. (Anal. ed.), 14, 67 I.

Harris, L. J. \& Raymond, W. D. (x939). Biochem. F. 33, 2037.

Kodicek, E. (1940a). Biochem. F. 34, 712 .

Kodicek, E. (1940b). Biochem. J. 34, 724.

Krehl, W. A., Elvehjem, C. A. \& Strong, F. M. (1944). Y. biol. Chem. 156, 13.

Krehl, W. A. \& Strong, F. M. (1944). F. biol. Chem. 156, I.

Melnick, D. \& Field, H. Jr. (1940a). \%. biol. Chem. 134, I.

Melnick, D. \& Field, H. Jr. (1940b). Y. biol. Chem. 135, 53. 
Melnick, D., Oser, B. L. \& Siegel, L. (1941). Industr. Engng Chem. (Anal. ed.), 13, 879.

Swaminathan, M. (1938-9). Indian Y. med. Res. 26, 426.

Swaminathan, M. (1942a). Indian $\mathscr{Y}$. med. Res. 30, 263.

Swaminathan, M. (1942 b). Indian Y. med. Res. 30, 397.

Swaminathan, M. (1942C). Indian F. med. Res. 30, 403 .

Swaminathan, M. (1944). Indian $\mathcal{Y}$. med. Res. 32, 39.

\title{
Stimulation of Growth in Pigs by Iodinated Casein and Stilboestrol*
}

\author{
BY R. BRAUDE \\ National Institute for Research in Dairying, University of Reading
}

(Received 16 February I950)

During the last few years attempts have been made in this Institute to affect various endocrine glands of the pig by giving by mouth synthetic preparations, and to find effects on rate of growth and food utilization which might have a practical application.

The results of trials with iodinated casein (Braude, 1947a) showed that with some pigs a slight increase in the rate of growth and food utilization could be obtained by stimulating their metabolic activity with thyroid-active preparations. No practical application, however, could be envisaged because of the very limited dose range in which the giving of the drug had a positive effect, and because of the great variation between individual animals in response to the treatment. It should, however, be mentioned here that Reineke, McMillen \& Bratzler (I948) claim that growth and development of pigs can be accelerated by suitably controlled administration of thyroprotein.

In another series of experiments with fattening pigs (Braude, $1947 \mathrm{~b}$, and unpublished data), it was observed that a slight increase in the rate of growth of castrated male animals, coupled with more efficient utilization of food, resulted from the giving of small amounts of stilboestrol, which acts on the pituitary gland. For practical application the effect was not substantial enough to warrant the trouble and expense connected with the treatment.

Much more promising results are now reported from four trials in which iodinated casein and stilboestrol were fed simultaneously. A preliminary note on the first two of these trials has been published (Braude, I 948).

\section{FXPERIMENTAL}

\section{Tests with pigs}

In all experiments, home-bred Large White pigs were used. At the end of the test all pigs were slaughtered and carcass measurements were taken according to the procedure described in detail by Shorrock (1940). The thyroid and pituitary glands were collected for histological examination.

- Read in part before the International Congress of Biochemistry (Braude, 1949). 